\title{
Factors determining healthy work conditions in the beauticians' workplace
}

\author{
Magdalena Stawarz $^{1 *}$, Małgorzata Makowska ${ }^{1}$, Sylwester Stawarz ${ }^{2}$
}

${ }^{1}$ The State School of Higher Education in Sandomierz, Poland

${ }^{2}$ University of Technology and Humanities in Radom, Poland

\begin{tabular}{ll}
\hline ARTICLE INFO & ABSTRACT \\
\cline { 1 - 1 } $\begin{array}{ll}\text { Received 20 December 2015 } \\
\text { Accepted 21 January 2016 }\end{array}$ & $\begin{array}{l}\text { The beauty studio is a place of work where a beautician and her customers spend several } \\
\text { hours, hence, it has to meet certain basic hygiene requirements so as to provide employees } \\
\text { Keywords: }\end{array}$ \\
$\begin{array}{ll}\text { and customers conditions that keep them safe and healthy. The main dangers to which } \\
\text { hygiene requirements, } \\
\text { healthy work conditions. }\end{array}$ & $\begin{array}{l}\text { beauticians are exposed, are of physical, chemical, biological and psychophysical nature. } \\
\text { Therefore, it is important to draw employees' attention to the possible effects of the } \\
\text { particular dangers and risks that come about when there is lack of the use of appropriate } \\
\text { preventive measures. }\end{array}$
\end{tabular}

\section{INTRODUCTION}

Hygiene requirements that should be met in the workplace mean following the long-established norms specifying the conditions that allow the preservation of the physical and mental health of people working in the particular place. Employees of beauty salons providing the services of hairdressing and beauty-enhancement, who, in Poland, constitute a large professional group, are exposed to many chemical, biological, biomechanical and acoustic agents during their work. The machinery and equipment of the profession are the main sources of noise in such a workplace. Here, such agents as the acoustic signals indicating the completion of device work cycle, the alarms, fans, air conditioners, air ducts, and level of conversation can be included in this category. Regarding chemical and biological agents, these are present in almost every workplace, including a beauty studio. Having daily contact with them, employees are not always aware of the impact that such factors have on their health. Indeed, a lot of products that are classified as being dangerous substances are in use within a beauty studio. Such agents cause various changes in the body, including harm to the nervous system, and they can trigger asthma or allergies and eye injury. Hence, employees of beauty studios should pay particular attention to the substances and preparations that they are dealing with at work, and use them in safe way, both for their and for their customers' benefit $[1,12,15]$.

\footnotetext{
* Corresponding author

e-mail: stawarz@uthrad.pl
}

\section{The analysis of occupational risk assessment in the workplace of beauticians}

In accordance with the requirements of Directive 98/24/ EC on the safety of workers and protecting their health from the risks related to chemical agents at work [3], as well as the regulations of the Minister of Health on health and safety related to the presence of chemical agents at work, employers are required to determine which chemicals, hazardous to the employees, are present in the work environment. Employers are also obliged to make and document the risk assessment caused by these factors [13].

The designing of a safe and ergonomic workplace requires action in several areas: knowledge of labour laws and their proper application and interpretation, awareness of accident risks by employees and supervisors, the competent execution of tasks by the workers of the environment, health and safety professions, correct safety instructions at the workplace, the prevention of musculoskeletal and mental (connected with stress) disorders, as well as the customizing of objects, machines and other devices fitted to the workplace so as to ensure safe and ergonomic usage. Such awareness and practice helps to reduce risks for various types of such systems as the musculoskeletal. Indeed, suitable breaks, the shortening of time of performing the same repetitive and tiring action, for example, during the completion of a manicure, is just one element that ensures long-term health $[6,14]$.

It is important for the beauty salon to be comprised of a minimum of two rooms. The treatment area should be 
a min. of $10 \mathrm{~m}^{2}$, while the waiting room should be $8 \mathrm{~m}^{2}$. The recommended ceiling height is $3.3 \mathrm{~m}$, yet in some situations, regulated by the relevant laws; it may be allowed to use a room with a height of $2.5 \mathrm{~m}$. Furthermore, the studio should be located in a separate building or premises, or constitute a separate part of it. Cleanliness and hygiene should be maintained in all the rooms. The decor of the rooms depends on the studio owner, but all the rooms should be neat and attractive, as well as being decorated in bright colours. The floor cannot be slippery and must be easy to clean. What is more, the walls of the studio should be covered to a height of at least $1.6 \mathrm{~m}$ with the material of a smooth surface that must be neither permeable nor absorb moisture, and which, as well, should be resistant to cleaning and disinfecting agents. All stairs should be clad with anti-skidding material. In addition, the entrance to the office cannot pose a risk for the customer; it must be collision-free, which means that anything directly near the front door must not interfere during a possible evacuation. Finally, the premises in such facilities where beautician services are provided, should have a surface which allows to such an arrangement, and to the installation and use of the equipment that ensures proper service and servicing [14].
It should be underlined that disinfection and sterilisation are crucial in a beauty salon in order to prevent the spreading of dangerous biological factors. Both physical and chemical methods are normally employed during the disinfection process, and approved chemical compounds that counter bacteria, viruses and fungi should be widely used in beauty salons. Such substances are applied to disinfect tools, appliances and surfaces. Sterilisation is a process as a result of which all germs and fungi are destroyed, including their vegetative forms, as well as their spores. Tool sterilisation with warm humid air in an autoclave is the most commonly utilised method in beauty salons. [5,14].

The standard workplace of a beautician consists of rooms with central heating, electrical supply, hot/cold water, ventilation, air conditioning, as well as daylight access and artificial light (general and local - shadowless lamp). The studio normally includes a separate room for hygienic and sanitary purposes (separate for employees and customers), a dressing-room and a waiting room for clients, a place to store equipment to maintain the cleanliness, and space for the collection of waste.

The room in which the treatments are performed includes swivelling cosmetic seats, treatment stools at each cosmetic seat and aid stools on wheels, cabinets for clean storage of

Table 1. Occupational risk at a beautician's workplace - physical, chemical and psychophysical dangers $[1,2,7,8,10,11]$

\begin{tabular}{|c|c|c|c|}
\hline No. & A danger or unsafe, harmful, disruptive factor & The source of danger & Possible results \\
\hline 1. & Slipping, tripping and falling on the same level & Mess at the workplace. Slippery shoes & $\begin{array}{l}\text { Strains of muscles and tendons, fractures, sprains, } \\
\text { bruises throughout the body }\end{array}$ \\
\hline 2. & Stumbling and falling onto a lower level & Walking on stairs & $\begin{array}{l}\text { Contusions, bruising all over the body, dislocation of } \\
\text { joints, muscle strain, fractures of the limbs }\end{array}$ \\
\hline 3. & Forced posture & $\begin{array}{l}\text { Working in a sitting position. Many hours of work at } \\
\text { a bent position }\end{array}$ & $\begin{array}{l}\text { Long-term and recurring disorders of musculo- } \\
\text { skeletal system. Rheumatic ailments, including } \\
\text { degenerative changes or inflammation of the } \\
\text { shoulder joint on the left side of the body }\end{array}$ \\
\hline 4. & Contact with polluted air & $\begin{array}{l}\text { The presence of compounds of an aromatic structure } \\
\text { (toluene and xylene), esters and ketones (ethyl } \\
\text { acetate, acetone) and terpenes and camphor, dusts }\end{array}$ & $\begin{array}{l}\text { The allergic reactions of the respiratory tracts or } \\
\text { irritation of } \\
\text { the conjunctivas and oral mucosa }\end{array}$ \\
\hline 5. & Contact with harmful chemicals & $\begin{array}{l}\text { Synthetic resins such as polyurethane and polyester } \\
\text { Dyes, preservatives, nail enamels, enamel } \\
\text { hardeners }\end{array}$ & $\begin{array}{l}\text { The allergic or irritant reaction of the respiratory } \\
\text { tracts and the skin }\end{array}$ \\
\hline 6. & Disinfectants & $\begin{array}{l}\text { Chlorine compounds, peroxide compounds, } \\
\text { alcohols, } \\
\text { quaternary ammonium compounds, phenolic } \\
\text { compounds }\end{array}$ & $\begin{array}{l}\text { Allergic reactions within the respiratory system, and } \\
\text { skin }\end{array}$ \\
\hline 7. & Overloaded eyesight & $\begin{array}{l}\text { Many hours of driving: } \\
\text { - direct and reflected solar radiation, } \\
\text { - blinding by other users while driving at night } \\
\text { Long-term work on the computer }\end{array}$ & $\begin{array}{l}\text { Eye fatigue, headaches and temporary malaise. } \\
\text { Pain in the eyeballs. Tearing, the phenomenon } \\
\text { of obfuscation. Changes within the skin, and eye } \\
\text { diseases }\end{array}$ \\
\hline 8. & Stress & $\begin{array}{l}\text { The management pressure related to work results } \\
\text { (especially in the case of failure in successful selling) } \\
\text { Many hours of trade negotiations (particularly in the } \\
\text { case of failure) The preparation of materials and } \\
\text { participation in tenders } \\
\text { Contacts with customers (service) Driving a car } \\
\text { Competition within the company Worrying about the } \\
\text { amount of salary and fear of losing the job } \\
\text { The work overload } \\
\text { No time for family life }\end{array}$ & $\begin{array}{l}\text { Neurosis, psychosis, gastrointestinal disease, } \\
\text { cardiovascular disease, insomnia, etc. }\end{array}$ \\
\hline 9. & Aggression on the part of people & Contacts with clients. Abuse from criminals & $\begin{array}{l}\text { Body injuries with hardly predictable effects } \\
\text { including the possibility of death }\end{array}$ \\
\hline 10. & Electricity & $\begin{array}{l}\text { Equipment powered by electricity (including } \\
\text { lighting). Faulty wiring in the workplace }\end{array}$ & Burns, loss of consciousness, cardiac arrest, death. \\
\hline 11. & Physical encounter with fixed elements & Elements of doors and equipment in the rooms & Body injuries, particularly dangerous head injuries \\
\hline 12. & Physical encounter with mobile elements & Sashes, doors & $\begin{array}{l}\text { Bruising of the body, most commonly fingers and } \\
\text { head injuries }\end{array}$ \\
\hline 13. & The contact with sharp, harsh edges & $\begin{array}{l}\text { Elements of cosmetic devices. The edges of the } \\
\text { packagings, beautician's tools: cuticle scissors, nail } \\
\text { files, etc }\end{array}$ & Cuts and punctures - usually of hands \\
\hline 14. & Fire & $\begin{array}{l}\text { Combustiblematerials, degreasers, solvents } \\
\text { gathered in the cosmetic offices }\end{array}$ & $\begin{array}{l}\text { Poisons with fire fumes containing carbon monoxide, } \\
\text { also burns, and sometimes even death }\end{array}$ \\
\hline 15. & Thermal burns & $\begin{array}{l}\text { During the preparation of coffee or tea - contact } \\
\text { with hot surfaces in the social room }\end{array}$ & Hands burns of first and second degree. \\
\hline 16. & Overload of the musculo-skeletal system & $\begin{array}{l}\text { Lifting, carrying packages with samples of products } \\
\text { or products supplied to the beauty salon }\end{array}$ & Injuries of the spine, shoulders, wrists \\
\hline
\end{tabular}


Table 2. Biological hazards at a beautician's workplace $[2,9,15]$.

\begin{tabular}{|r|l|l|l|}
\hline \multirow{2}{*}{ No. } & \multicolumn{1}{|c|}{ Hazard } & \multicolumn{1}{|c|}{ The source of danger } & \multicolumn{1}{|c|}{ Group of infection } \\
\cline { 2 - 4 } 1. & Influenza virus (type A, B, C) orthomyxovirdae & $\begin{array}{l}\text { People } \\
\text { By air-droplet }\end{array}$ & Influenza, pneumonia \\
\hline 2. & Staphylococcus aureus & $\begin{array}{l}\text { People } \\
\text { By air-droplet. airborne dust, food, direct contact }\end{array}$ & $\begin{array}{l}\text { Purulent infections, inflammation of the upper } \\
\text { respiratory tracts, skin allergy }\end{array}$ \\
\hline 3. & Mycobacterium tuberculosis & $\begin{array}{l}\text { People } \\
\text { By air-droplet }\end{array}$ & Pulmonary tuberculosis, rarely in other organs \\
\hline 4. & Salmonella choleraesuis & $\begin{array}{l}\text { Water, plant and animal products, meals at work } \\
\text { By oral contact }\end{array}$ & Salmonellosis, gastroenteritis, food poisoning \\
\hline 5. & Hepatitis infections type B and C & Cut, contact with client's blood & Fatal disease, death \\
\hline 6. & AIDS infection & Cut, contact with client's blood & Death \\
\hline 7. & Allergy & $\begin{array}{l}\text { Applied chemicals, disinfecting tools, position of } \\
\text { equipment }\end{array}$ & Skin allergies, asthma \\
\hline 8. & Scabies & Contact with clients & Disease, work-place absence \\
\hline 9. & Mycosis & Contact with clients, contact with water & Disease, work-place absence \\
\hline
\end{tabular}

over-clothing and customer clothing, a basket for holding dirty treatment clothes, cabinets containing preparations, equipment and tools, warming lamps, devices for humidification, for plating and heating items such as waxes, thermal masks and masks for iontophoresis etc., sterilizers for tools, and devices that use a combination of technology (I.e. light waves (IPL) and radio frequency (RF)) for cosmetic and medical treatments.

While performing their tasks, a beautician should use clean bowls, brushes and spatulas, sterile disposable equipment and supplies, sterile scissors, razors and nail files [4].

Despite so many possible threats contained within the cosmetologist's workplace, yet not all beauticians are aware of the problem. Table 1 presents the normal occupational risks encountered within a beautician's workplace, while Table 2 shows the biological hazards typically met with by beauticians. Polish Law [14] sets out detailed requirements to be met by beauty salons, tattoo studios and wellness centres. It recommends the use of disposable instruments and prohibits their re-use. Such tools should be treated as being medically dangerous, and ought to be isolated within airtight containers and disposed of immediately after use - in accordance with the regulations of the Waste Act.

Therefore, it seems justified to train beauticians, as well as control beauty salons by way of frequent health inspections. What is more, health and safety classes are indispensable at all levels of a beautician's and cosmetologist's training.

\section{CONCLUSIONS}

The variety of dangers in the beauticians' workplace requires the continuous improvement of techniques and organization of work, including direct protection of both client and professional. The awareness of management and employees is particularly important in ergonomic risk assessment. Therefore, educational workshops should deal with, among other issues: (I) techniques, e.g. in terms of moving equipment or carrying it, of how to perform a given activity in a suitably ergonometric manner; (II) the principles of biomechanics, thereby awareness of the potential occurrence of musculoskeletal disorders, as well as ensuring employees understand better ways of being continuously ergonomically safe; (III) the need for physical exercise for improving body condition, hence, ensuring that the human body is not as susceptible to possible injuries; (IV) best hygiene practices based on paying attention to biological threats; (V) chemical hazard reduction of working time in terms of exposure to chemical agents; through airing or need for installing suitable ventilation systems; (VI) ensuring the availability of Safety Data Sheets for dangerous substances and preparations; (VII) measurements of concentrations of chemical substances in workplace air, if necessary.

\section{REFERENCES}

1. Bilski B., Marynowicz B.: Knowledge and hygienic behaviour, as well as the risk of incidents posing a risk of hematogenous infection within a selected population of personnel of beauty and hairdresser's studios. Med. Pr., 57, 517, 2006. (in Polish).

2. Braun-Falco O., Plewig G., Wolff H.H., Burgdorf W.H.C. (2004) Dermatology. Wydawnictwo Czelej, Lublin. (in Polish)

3. Council Directive 98/24/ EC of 7 April 1998 on the protection of health and safety of workers from the risks related to chemical agents at work. Official Journal No L 131, 5.5.1998, p.11-23.

4. Dylewska-Grzelakowska J. (2013). Applied Cosmetics. WSiP, Warszawa. (in Polish).

5. Fraise A. P., Lambert P. A., Maillard J.-Y. (2004) Russell, Hugo \& Ayliffe's principles and practice of disinfection, preservation and sterilization. Wiley Blackwell.

6. Górska E.: (2000) Ergonomic diagnosis of workplaces. Oficyna Wydawnicza Politechniki Warszawskiej, Warszawa. (in Polish).

7. Jakubowski M.: Documentation of limits of occupational exposure values. Podstawy i Metody Oceny Środowiska Pracy 47, 109, 2006. (in Polish)

8. Kanerva L., Elsner P., Wahlberg J., Maibach H. I., editors (2004) Condensed Handbook of Occupational Dermatology. SpringerVerlag Berlin Heidelberg.

9. Kieć-Świerczyńska M., Chomiczewska-Skóra D. ŚwierczyńskaMachura D. Kręcisz B.: Manicurists and pedicurists as a professional group with a significant risk of work-related dermatoses. Med. Pr., 64, 579, 2013. (in Polish)

10. Kurpiewska J., Liwkowicz J.: The efficacy of skin protection applied by beauticians. Bezpieczeństwo Pracy. Nauka i Praktyka, 2, 12, 2003. (in Polish)

11. Kurpiewska J., Liwkowicz J.: Skin protection - definitions, types, application, risk assessment and applicable legal regulations in Poland. Bezpieczeństwo Pracy. Nauka i Praktyka, 6, 23, 2010. (in Polish)

12. Murawska-Ciałowicz E. Zawadzki M. (2005). Hygiene. Górnicki Wydawnictwo Medyczne, Wrocław. (in Polish) 
13. Regulation of the Minister of Health of 30 December 2004 on health and safety related to occurrence of chemical agents at work. Dz. U. z 2005 r., Nr 11, poz. 86. (in Polish).

14. Regulation of the Minister of Health of 17 February 2004 on specific sanitary requirements to be met by hairdresser's, cosmetic, tattoo and wellness studios. Dz. U. z 2004 r., Nr 31, poz. 273. (in Polish)

15. Regulation of the Minister of Health of 22 April 2005 on the harmful biological factors for health in the workplace and on protecting the health of workers occupationally exposed to these factors. Dz. U. z 2005 r., Nr 81, poz. 716. (in Polish) 